\title{
The Influence of Gestational Age and Birth Weight on Neonatal Mortality
}

\author{
Wedi Iskandar, ${ }^{1}$ Yeni Andayani, ${ }^{1}$ Lia Marlia, ${ }^{1}$ Burhan, ${ }^{1}$ Aris Primadi ${ }^{2}$ \\ ${ }^{1}$ Department of Child Health, Faculty of Medicine, Universitas Islam Bandung/Al Islam Hospital Bandung, \\ Bandung, Indonesia, ${ }^{2}$ Department of Child Health, Faculty of Medicine, Universitas Padjadjaran/ \\ Dr. Hasan Sadikin General Hospital, Bandung, Indonesia
}

\begin{abstract}
Prematurity and low birth weight are some of the causes of neonatal death and significant health problem. This study aimed to determine the influence of gestational age and birth weight on neonatal mortality at the $\mathrm{Al}$ Islam Hospital Bandung in 2015-2019. It was a case-control retrospective observational analysis using medical records of the Al Islam Bandung Hospital from January 1, 2015, to December 31, 2019. The inclusion criteria for infants were born alive. Exclusion criteria had severe congenital abnormalities and gestational age <26 weeks. The chisquare test evaluated the univariate comparison test of risk factors between 2 groups. Multiple logistic regression to assess neonatal mortality's predictive factors and the percentage contribution of the influence was calculated (Nagelkerke's R² analysis). The number of infants enrolled in 2015-2019 was 6,791 neonates, and who died was 56 neonates (0.82\%). In premature infants and low birth weight there was a very significant relationship with neonatal mortality, respectively $\mathrm{p}=0.000(\mathrm{p}<0.05) \mathrm{OR}=30.397(\mathrm{CI}=16.506-55.976)$, and $\mathrm{p}=0.000(\mathrm{p}<0.05) \mathrm{OR}=41.206$ $(\mathrm{CI}=18.611-91.233)$. In the multiple logistic regression test, $\mathrm{p}=0.000(\mathrm{p}<0.05)$, with a Nagelkerke's $\mathrm{R}^{2}$ value of 0.344 or $34.4 \%$. This presence that gestational age and birth weight significantly affects neonatal mortality, either partially or simultaneously. The percentage contribution of the influence of gestational age and birth weight to neonatal mortality was $34.4 \%$.
\end{abstract}

Keywords: Low birth weight, neonatal mortality, premature

\section{Pengaruh Usia Gestasi dan Berat Badan Lahir terhadap Kematian Neonatus}

\begin{abstract}
Abstrak
Prematuritas dan berat badan lahir rendah merupakan beberapa penyebab kematian neonatus dan masalah kesehatan yang signifikan. Penelitian ini bertujuan mengetahui pengaruh usia gestasi dan berat badan lahir terhadap kematian neonatus di RS Al Islam Bandung tahun 2015-2019. Penelitian ini merupakan penelitian observasional retrospektif kasus kontrol menggunakan data rekam medis RS Al Islam Bandung periode 1 Januari 2015 hingga 31 Desember 2019. Kriteria inklusi bayi lahir hidup. Kriteria eksklusi bayi dengan kelainan kongenital berat dan usia gestasi <26 minggu. Uji chi-square mengevaluasi perbandingan univariat faktor risiko antara 2 grup. Regresi logistik multipel untuk mengevaluasi faktor prediktif kematian neonatus dan persentase kontribusi pengaruh dihitung (Analisis $\mathrm{R}^{2}$ Nagelkerke). Jumlah bayi yang dirawat tahun 2015-2019 sebanyak 6.791 dan yang meninggal sebanyak 56 (o,82\%). Pada bayi lahir prematur dan berat badan lahir rendah terdapat hubungan sangat bermakna terhadap kematian neonatus, berturut-turut $\mathrm{p}=0,000(\mathrm{p}<0,05) \mathrm{OR}=30,397(\mathrm{CI}=16,506-55,976)$ dan $\mathrm{p}=0,000(\mathrm{p}<0,05) \mathrm{OR}=41,206(\mathrm{CI}=18,611-91,233)$. Pada uji regresi logistik multipel, $\mathrm{p}=0,000(\mathrm{p}<0,05)$ dengan nilai $\mathrm{R}^{2}$ Nagelkerke sebesar 0,344 atau $34,4 \%$. Usia gestasi dan berat badan lahir berpengaruh bermakna terhadap kematian neonatus, baik secara parsial maupun simultan. Persentase sumbangan pengaruh usia gestasi dan berat badan lahir terhadap kematian neonatus sebesar 34,4\%.
\end{abstract}

Kata kunci: Berat badan lahir rendah, kematian neonatus, prematur

Received: 24 September 2020; Revised: 3 December 2020; Accepted: 17 December 2020; Published: 31 December 2020 Correspondence: Wedi Iskandar, dr., Sp.A. Department of Child Health, Faculty of Medicine, Universitas Islam Bandung/Al Islam Hospital Bandung. Jln. Soekarno Hatta No. 644, Bandung 40286, West Java, Indonesia. E-mail: wedi_iskandar@yahoo.com 


\section{Introduction}

Prematurity and low birth weight are some of the causes of neonatal death in the world and a major health problem. ${ }^{1}$ Low birth weight (newborns weighing less than 2,500 grams at birth), due to premature and limited growth in the uterus, is also a significant contributor to neonatal and child mortality, as well as disabilities and noncommunicable diseases globally. ${ }^{2}$

Of the fifteen million infants born each year prematurely, more than one million die from preterm birth complications. ${ }^{2}$ The proportion of deaths according to $\mathrm{WHO}$, neonatal prematurity was 14 percent in 2000, increased to 15 percent in 2001-2005 and 16 percent in 2006-2008, and continued to increase to 17 percent in 20092011. ${ }^{1}$ Indonesia has a neonatal mortality rate of 14 per 1,000 live births based on data from 2015, which is the $10^{\text {th }}$ highest mortality rate in the world. The neonatal mortality rate is even higher if only rural births are included, estimated at 24 deaths per 1,00o live births. A large portion of this mortality is related to the high prevalence of premature infants. ${ }^{3}$

More than $30 \%$ of global infant mortality rates are caused by low birth weight (LBW) infants. ${ }^{1}$ In Indonesia, infant mortality due to LBW is estimated to reach as high as $29 \%$. Alisyahbana et al., ${ }^{4}$ a population-based cohort study in Tanjungsari, a rural subdistrict of West Java, Indonesia, in the neonatal period the proportion of deaths in LBW infants (34.1\%) and preterm (18\%).

Nearly $85 \%$ of preterm infants are born between 32 and 37 weeks of gestation, and most of these infants do not receive intensive survival care. This intensive care is a solution to improve vulnerable premature and low birth weight infants' survival and health. More effort is needed to identify women at risk of preterm labor and support them to deliver in a health facility that can offer extra care when needed. To do this, families, communities, and health workers must value young infants to receive the rescue care they need. ${ }^{2}$

Until now, many studies have evaluated the relationship or influence of risk factors on prematurity, low birth weight on neonatal mortality. However, the influence of these risk factors on neonatal mortality, either partially or simultaneously, is not yet studied using the Nagelkerke's $\mathrm{R}^{2}$ analysis. ${ }^{5}$ Therefore, the study aims to determine the influence of gestational age and birth weight on neonatal mortality were treated at the Al Islam Bandung Hospital in 2015-2019. The results of this study are expected to be a source of information for the scientific community and specifically become benchmarks for planning better neonatal care at the $\mathrm{Al}$ Islam Bandung Hospital.

\section{Methods}

This study is a case-control retrospective observational analysis, using secondary data from the medical records of the $\mathrm{Al}$ Islam Bandung Hospital during 2015-2019. The inclusion criteria for infants born alive and treated in the neonatology unit of Al Islam Hospital Bandung from January 1, 2015, to December 31, 2019, exclusion criteria for severe congenital abnormalities, gestational age less than 26 weeks. The sample size was calculated using the total sampling technique for the case group and the control group.

For data analysis, subjects were divided into dead infants (case group) and live infants (control group)-the study's independent variables as risk factors for neonatal mortality, gestational age, and birth weight. A univariate comparison test of risk factors was carried out between the two groups, evaluated by the chi-square test, significance based on $\mathrm{p}$ value $<0.05$. Multiple logistic regression was used to assess neonatal mortality's predictive factors, and the percentage contribution of the effect was calculated (Nagelkerke's $\mathrm{R}^{2}$ analysis). Model suitability was checked statistically by the Hosmers Lemeshow test. Statistical analysis using SPSS-25 software. Ethical clearance for this study was obtained from the Health Research Ethics Committee of Applied Al Islam Hospital Bandung with the issuance of the ethical clearance Number 0011/ KEPK-RSAI/09/2020.

\section{Results}

The number of infants enrolled in the Al Islam Hospital Bandung's neonatology unit for 20152019 was 6,791 neonates. Total coverage based on gestational age, 647 (9.5\%) infants were born preterm ( $<37$ weeks), and 6,144 (90.5\%) were born at maturity. Total coverage based on birth weight, 1,010 (14.9\%) infants born with low birth weight $(<2,500$ grams), and 5,781 (85.1\%) were born with normal birth weight $(>2,500$ grams; Table 1). 
Table 1 Infant Coverage based on Gestational Age and Birth Weight

\begin{tabular}{lrr}
\hline Categories & $\mathbf{n = 6 , 7 9 1}$ & $\mathbf{\%}$ \\
\hline Gestational age (weeks) & & \\
$<37$ & & \\
26 to 28 & 49 & 0.7 \\
28 to $31+6$ & 109 & 1.6 \\
32 to $34+6$ & 208 & 3.1 \\
35 to $36+6$ & 281 & 4.1 \\
Subtotal & 647 & 9.5 \\
$\geq 37$ & 6,144 & 90.5 \\
Birth weight (grams) & & \\
$<2,500$ & & \\
$<1$, ooo & 43 & 0.6 \\
1,000 to 1,499 & 110 & 1.6 \\
1,500 to 1,999 & 222 & 3.3 \\
2,000 to 2,499 & 635 & 9.4 \\
Subtotal & 1,010 & 14.9 \\
$\geq 2,500$ & 5,781 & 85.1 \\
\hline
\end{tabular}

Of the 6,791 neonates enrolled during 20152019, 56 (0.8\%) neonates experienced death. Characteristics of 56 neonates who died, 42 $(75 \%)$ died at $<37$ weeks (premature) and 49 (87.5\%) died with birth weight $<2,500$ grams (LBW, Table 2).

Based on gestational age, infants born prematurely had a very significant relationship with $\mathrm{p}=0.000(\mathrm{p}<0.05)$ on neonatal mortality with an OR of $30.397(\mathrm{CI}=16.506-55.976)$. Based on birth weight, LBW had a very significant relationship with $\mathrm{p}=0.000(\mathrm{p}<0.05)$ on neonatal mortality with $\mathrm{OR}=41.206 \quad(\mathrm{CI}=18.611-91.233$; Table 2).

Multiple logistic regression tests determine the independent variables (gestational age, birth weight) on the dependent variable (neonatal mortality) simultaneously. Table 3 shows that the Sig regression $\mathrm{p}=0.000(\mathrm{p}<0.05)$, which means
Table 3 Logistic Regression Analysis, Summary Model

\begin{tabular}{lcccc}
\hline Step 1 & $\begin{array}{c}\text { Chi- } \\
\text { square }\end{array}$ & df & Sig & $\begin{array}{c}\text { Nagelkerke } \\
\mathbf{R}^{\mathbf{2}}\end{array}$ \\
\hline Step & 216.478 & 2 & 0.000 & 0.344 \\
Block & 216.478 & 2 & 0.000 & \\
Model & 216.478 & 2 & 0.000 & \\
\hline
\end{tabular}

that gestational age, birth weight simultaneously had a significant effect on the occurrence of neonatal mortality. It was found that Nagelkerke's $\mathrm{R}^{2}$ was 0.344 or $34.4 \%$. This shows that the percentage contribution of the independent variables (gestational age, birth weight) to the dependent variable (neonatal mortality) was $34.4 \%$, meaning that $65.6 \%$ of other risk factors affect neonatal mortality (Table 3 ).

\section{Discussion}

Premature infants are prone to severe illness or death during the neonatal period. Without adequate treatment, surviving infants are at increased risk of lifelong disabilities and low quality of life. Premature complications are the largest cause of newborn mortality and the second leading cause of death among children under five years. Global efforts to further reduce child mortality require urgent action to tackle preterm births. ${ }^{6}$ Low birth weight is a significant health problem, resulting in 20 to 30 times higher morbidity and mortality rates than in infants with normal birth weight. More than 30\% of global infant mortality rates are caused by LBW. ${ }^{7}$ In Indonesia, infant mortality due to LBW is estimated to reach as high as $29 \% .^{8}$ The high mortality rates are caused by LBW complications, such as hypothermia, hypoglycemia, asphyxia,

Table 2 Univariate Analysis of Gestational Age and Birth Weight on Neonatal Mortality (Chi-square Test)

\begin{tabular}{|c|c|c|c|c|c|c|c|}
\hline \multirow{2}{*}{$\begin{array}{l}\text { Gestational Age and } \\
\text { Birth Weight }\end{array}$} & \multirow{2}{*}{$\begin{array}{c}\text { Case } \\
n=56(\%)\end{array}$} & \multirow{2}{*}{$\begin{array}{c}\text { Control } \\
\mathrm{n}=6,735(\%)\end{array}$} & \multirow{2}{*}{$\begin{array}{c}\text { Total } \\
\mathbf{n}=\mathbf{6 , 7 9 1}(\%)\end{array}$} & \multirow{2}{*}{$\begin{array}{c}\mathbf{p} \\
\text { Value }\end{array}$} & \multirow{2}{*}{ OR } & \multicolumn{2}{|c|}{$95 \%$ CI } \\
\hline & & & & & & Lower & Upper \\
\hline $\begin{array}{l}\text { Gestational age (weeks) } \\
<37 \text { weeks } \\
>37 \text { weeks }\end{array}$ & $\begin{array}{l}42(6.5) \\
14(0.2)\end{array}$ & $\begin{array}{c}605(93.5) \\
6,130(99.8)\end{array}$ & $\begin{array}{c}647(100) \\
6,144(100)\end{array}$ & 0.000 & 30.397 & 16.506 & 55.976 \\
\hline $\begin{array}{l}\text { Birth weight (grams) } \\
\quad<2,500 \\
>2,500\end{array}$ & $\begin{array}{l}49(4.8) \\
7(0.1)\end{array}$ & $\begin{array}{c}978(95.2) \\
5,757(99.9)\end{array}$ & $\begin{array}{l}1,034(100) \\
5,757(100)\end{array}$ & 0.000 & 41.206 & 18.611 & 91.233 \\
\hline
\end{tabular}


and respiratory distress syndrome (RDS). Other complications were apnea, chronic lung disease (CLD), cardiovascular problem, neurologic disorder, anemia, fluid and electrolyte imbalance, hyperbilirubinemia, malnutrition, sepsis. ${ }^{8-10}$

In this study, there were 42 preterm infant deaths (75\%), and it is statistically proven that gestational age has a significant effect on neonatal mortality. In univariate analysis, preterm infants had a very significant relationship with $\mathrm{p}=0.000$ ( $\mathrm{p}<0.05)$ on neonatal mortality with an OR of 30.397 ( $\mathrm{CI}=16.506-55.976$ ). According to Sari and Syarif, ${ }^{8}$ the relationship between prematurity and neonatal mortality showed that there was a statistically significant relationship $(\mathrm{p}<0.001)$ with the crude OR of 13.44 ( $95 \%$ CI=7.16-25.55). Meanwhile, Cupen et al. ${ }^{11}$ showed that very low to extremely low birth weight $(\mathrm{OR}=15.41, \mathrm{CI}=2.00-$ $120.34, p=0.01$ ) were identified as significant risk factors for preterm neonatal mortality.

In this study, the percentage of LBW was 49 infants (87.5\%), and statistically, it was proven that birth weight had a significant effect on neonatal mortality. Pepler et al. ${ }^{12}$ based on their study, birth weight significantly influence the odds of neonatal death. This result is supported by research by Suparmi et al., ${ }^{13}$ which states that infants with LBW have a 9.89 times risk of dying than neonatal infants born with average weight. Other results suggest that LBW is a strong predictor of neonatal mortality, with LBW infants 5.5 times more likely to experience death. In Indonesia, LBW prevalence has decreased from $9-30 \%$ in 2002 to $7.2-16.8 \%$ in 2013 , depending on regional socioeconomic status. ${ }^{14} \mathrm{In}$ South Borneo, LBW prevalence is relatively high at $16.6 \%$ of total live births. ${ }^{15}$

In this study, gestational age and birth weight simultaneously had a significant effect on neonatal mortality. The impact of gestational age and birth weight on neonatal mortality was $34.4 \%$, meaning that $65.6 \%$ of other risk factors contributed to neonatal mortality, such as; maternal factors, health personnel handling aspects, and care facilities. Meanwhile, in research conducted by Hidayah and Hafidh ${ }^{16}$ at the Moewardi Hospital in Surakarta, the risk factors significantly correlated with neonatal mortality in the univariate analysis included preterm, low birth weight, sepsis, maternal age $>35$, and non-spontaneous delivery. When these factors were evaluated using regression analysis, only preterm, low birth weight, and sepsis were significantly associated with neonatal mortality.
In general, maternal factors play a significant role in the fetus's survival and the baby itself. However, in the multivariate analysis, the significant relationship to infant mortality was only childbirth factors $(\mathrm{OR}=2.6,95 \% \mathrm{CI}=1.2-5.5)$ and maternal contact with health workers $(\mathrm{OR}=2.1$, 95\% CI $=1.4-3,4) .{ }^{17}$ Meanwhile, Cupen et al. ${ }^{11}$ in the multivariate binary logistic regression for the maternal variables. Obstetric complications $(\geq 1$, $\mathrm{OR}=8.73,95 \% \mathrm{CI}=1.07-71.09, \mathrm{p}=0.04$ ) were the only significant risk factor for preterm neonatal mortality.

It indicates that the prematurity in the above model shows a role in neonatal mortality. To reduce infant mortality, increasing attention to services during the neonatal period is important. The resulting model also indicates the need for attention from various parties to premature birth cases at the service level. ${ }^{3}$ Neonatal health will need to be addressed more effectively for progress on overall child mortality to continue rapidly. Further reductions in neonatal deaths, in particular, depend on building more robust health services, ensuring that every birth is attended by skilled personnel, and making hospital care available in an emergency. Every newborn action plan endorsed by governments, the private sector, and civil society calls for reducing neonatal mortality rates in all countries to fewer than 10 deaths per 1,00o live births by $2035 .{ }^{3}$ Many of the conditions leading to early neonatal death in lowincome countries are preventable with relatively easy and cost-effective interventions. It requires educated and equipped health care workers, especially those with midwifery skills, training in resuscitation practices, simplified algorithms. Early detection of perinatal infections, early initiation of breastfeeding and skin-to-skin care (kangaroo mother care), contraception, vaccination of pregnant women, and hygienic delivery at a hospital were some programs to decrease mortality. The provision of essential commodities such as antenatal corticosteroids, resuscitation devices, injectable antibiotics, and chlorhexidine for clean cord care was also important. ${ }^{7,19,20}$ The same requirements are needed for the management of serious illness later in the neonatal period that might be detected by community health workers and referred for treatment. ${ }^{21}$

Preterm birth requires adequate newborn care, while premature infants need intensive care with complete hospital equipment. ${ }^{18}$

Premature cases require financial guarantees 
so that special service needs for newborns can be met. Service providers and people who experience premature birth conditions are not burdened with financing problems. $^{21}$ Preterm birth is increasingly common with substantial medical, economic, and social impact as it is invariably associated with acute and chronic complications. The median cost per infant increased with the level of care and degree of prematurity. The cost was dominated by overhead (fixed) costs for general (hospital), intermediate (clinical support services), and final (NICU) cost centers, where it constituted at least three-quarters of admission cost per infant. At the same time, the remainder was consumables (variable) cost. Breakdown of overhead cost showed NICU specific overhead contributing at least two-thirds of admission cost per infant. Personnel salary made up threequarters of NICU specific overhead. ${ }^{22}$ Many studies have reported that NICU costs are closely related to gestational age, the severity of illness, and the need for mechanical ventilation. The mean length of hospital stay was $13.6 \pm 13.4$ days. Hundred and four (49.5\%) patients were found to be ventilated. The median ventilation day was three days. We found a statistically significant relationship between hospital stay length, ventilation duration, presence of intervention, respiratory distress syndrome (RDS), sepsis, and hospital costs. The mean total hospitalization cost and the preterm's daily costs were 4,187 USD and 303 USD, respectively. ${ }^{23}$

Efforts to treat prematurity to prevent neonatal mortality are a significant investment for the nation and state because they have an impact on indicators of neonatal mortality and infant mortality rates. The reduction in the child mortalityindicator will increase thelifeexpectancy at birth to increase the public health status. ${ }^{21}$ The Regulation of the Minister of Health (Permenkes) Number 25 of 2014 concerning health efforts states that low or premature newborns require standard treatment. ${ }^{18}$ Every preterm newborn who gets adequate treatment can prevent neonatal deaths to reduce infant mortality automatically. ${ }^{3}$ If the Indonesian government wants to reduce child mortality, infant mortality, and neonatal mortality, it needs special attention to premature and LBW infants. For that, a program to save premature infants and LBW is required. Every effort to keep premature infants/ LBW is a long-term investment because every baby that is rescued contributes to improving the community's welfare and contributes to global health efforts. ${ }^{24}$

\section{Conclusions}

This study concludes that in the 2015-2019 Al Islam Hospital Bandung, the highest cause of death was prematurity. Gestational age and birth weight partially have a significant impact on neonatal mortality, and gestational age and birth weight simultaneously impact neonatal mortality. The percentage contribution of the influence of gestational age and birth weight to neonatal mortality was $34.4 \%$. Further research is needed to determine maternal risk factors for neonatal mortality.

\section{Conflict of Interest}

All authors stated that there no conflict of interest in this study.

\section{Acknowledgments}

Thank you to the Director of Al Islam Hospital Bandung for providing the opportunity to carry out this research, and pediatrician colleagues and nurses in the neonatology unit of Al Islam Hospital Bandung have facilitated this research to completion.

\section{References}

1. World Health Organization. Global death child causes. Geneva: World Health Organization; 2020.

2. Every Preemie-SCALE. Indonesia: profile of preterm and low birth weight prevention and care [Internet]. Washington, DC: Every Preemie-SCALE; 2019 May [cited 2019 September 3]. Available from: https:// www.everypreemie.org/wp-content/ uploads/2019/07/Indonesia_7-5.19.pdf.

3. United Nations Children's Fund. Maternal and newborn health disparities: Indonesia [Internet]. New York: United Nations Children's Fund; 2018 September [cited 2019 September 10]. Available from: https:// data.unicef.org/wp-content/uploads/ country_profiles/Indonesia/Maternal\%20 and\%2onewborn\%2ohealth\%20country\%20 profiles/country\%2oprofile_IDN.pdf.

4. Alisjahbana B, Rivami DS, Octavia L, Susilawati N, Pangaribuan M, Alisjahbana $\mathrm{A}$, et al. Intrauterine growth retardation 
(IUGR) as determinant and environment as modulator of infant mortality and morbidity: the Tanjungsari Cohort Study in Indonesia. Asia Pac J Clin Nutr. 2019;28(Suppl 1):S1731.

5. del Río R, Thió M, Bosio M, Figueras J, Iriondo M. Prediction of mortality in premature neonates. An updated systematic review. An Pediatr (Barc). 2020;93(1):24-33.

6. World Health Organization. WHO recommendations on intervention to improve preterm birth outcomes. Geneva: World Health Organization; 2015.

7. United Nations Childrens's Fund. Levels and trends in child mortality 2014 [Internet]. New York: United Nations Childrens's Fund; 2014 September [2019 October 1]. Available from: https://data.unicef.org/wp-content/ uploads / 2015/12/unicef-2013-childmortality-report-LR-10_31_14_195.pdf.

8. Sari TW, Syarif S. Hubungan prematuritas dengan kematian neonatal di Indonesia tahun 2010 (analisis data Riskesdas 2010). J Epidemiologi Kesehat Indones. 2016;1(1):914 .

9. Smith VC. The high-risk newborn: anticipation, evaluation, management, and outcome. In: Eichenwald EC, Hansen AR, Martin CR, Stark AN, editors. Cloherty and Stark's manual of neonatal care. $8^{\text {th }}$ edition. Philadelphia: Wolters Kluwer; 2017.p. 76-93.

10. Gomella TL, Eyal FG, Bany-Mohammed F, editors. Gomella's neonatology: management, procedures, on-call problems, diseases, and drugs. $8^{\text {th }}$ edition. New York: McGraw-Hill Education; 2020.

11. Cupen K, Barran A, Singh V, Dialsingh I. Risk factors associated with preterm neonatal mortality: a case study using data from Mt. Hope Women's Hospital in Trinidad and Tobago. Children (Basel). 2017;4(12):108.

12. Pepler PT, Uys DW, Nel DG. Predicting mortality and length-of-stay for neonatal admissions to private hospital neonatal intensive care units: a Southern African retrospective study. Afr Health Sci. 2012;12(2):166-73.

13. Suparmi, Chiera B, Pradoko J. Low Birth weight and risk of neonatal mortality in Indonesia. Health Sci $\mathrm{J}$ Indones. 2016;7(2):113-7.
14. Badan Penelitian dan Pengembangan Kesehatan, Kementerian Kesehatan Republik Indonesia. Penyajian pokok-pokok hasil riset kesehatan dasar 2013 [Internet]. Jakarta: Badan Penelitian dan Pengembangan Kesehatan, Kementerian Kesehatan Republik Indonesia; 2013 [cited 2019 November 5]. Available from: https://pusdatin.kemkes. go.id/article/view/MCN-20141230001/infoterkini-riskesdas-2013.html.

15. Astria Y, Suwita CS, Suwita BM, Widjaya FF, Rohsiswatmo R. Low birth weight profiles at H. Boejasin Hospital, South Borneo, Indonesia in 2010-2012. Paediatr Indones. 2016;56(3):155-61.

16. Hidayah $D$, Hafidh Y. Risk factors for neonatal mortality at Moewardi Hospital, Surakarta. Paediatr Indones. 2014;54(4):219-22.

17. Tarigan IU, Afifah T, Simbolon D. Faktorfaktor yang berhubungan dengan pelayanan bayi di Indonesia: pendekatan analisis multilevel. J Kesehat Reprod. 2017;8(1):10318.

18. Peraturan Menteri Kesehatan Republik Indonesia Nomor 25 Tahun 2014 tentang Upaya Kesehatan Anak.

19. Lehtonen L, Gimeno A, Parra-Llorca A, Vento M. Early neonatal death: a challenge worldwide. Semin Fetal Neonatal Med. 2017;22(3):153-60.

20. Haksari EL. Low birthweight and preterm infants in Indonesia. NeoReviews. 2019;20(10):e548-6o.

21. Cooper P. Strategies to reduce perinatal mortality. Lancet Glob Health. 2016;4(1):e67.

22. Zainal H, Dahlui M, Soelar SA, Su TT. Cost of preterm birth during initial hospitalization: a care provider's perspective. PLoS One. 2019;14(6):e0211997.

23. Cömert S, Ağzıkuru T, Akin Y, Telatar B, Tan PD, Ergen SG, et al. The cost analysis of preterm infants from a NICU of a state hospital in Istambul. Iran J Pediatr. 2012;22(2):185-90.

24. Pelangi B, Anindhita F, Susanti L. Penelitian kebijakan: efektivitas jaminan kesehatan nasional untuk menurunkan angka kematian ibu: pengalaman bidan dan perempuan di Jakarta Timur dan Kota Bandung. Jakarta: Women Research Institute: 2015. 